九州大学学術情報リポジトリ

Kyushu University Institutional Repository

\title{
The Chrysomelidae of Japan and the Ryukyu Islands. VI : Subfamily Galerucinae I
}

Kimoto, Shinsaku

Hikosan biological Laboratory, Department of Agriculture, Kyushu University

https://doi.org/10.5109/22724

出版情報: 九州大学大学院農学研究院紀要. 13 (2)，pp. 287-308，1964-10. Kyushu University バージョン：

権利関係 : 
Journal of the Faculty of Agriculture, Kyushu University, Vol. 13, No. 2

October 30, 1964

\title{
The Chrysomelidae of Japan and the Ryukyu Islands. VI ${ }^{1,2)}$ Subfamily Galerucinae I
}

\author{
Shinsaku KIMOTo ${ }^{3)}$
}

\section{Subfamily GaLerucinae}

\section{Key to Japanese genera of Galerucinae}

1. Mesosternum horizontal or inclined, not covered by a process of metasternum

Mesosternum with a somewhat convex, immarginate, long median process which is covering the entire horizontal surface of mesosternum . . . . . . ...33

2. Antennal insertions generally close, at level of anterior margins of eyes or further anterior, occiput and pronotum deeply punctate; last abdominal segment of male with a triangular or rounded depression with posterior border often emarginate, but never trilobed

Antennal insertions generally separated, situated near, but behind anterior borders of eyes; when separated or placed further forward, occiput and pronotum not heavily punctate ; last abdominal segment of male trilobed,

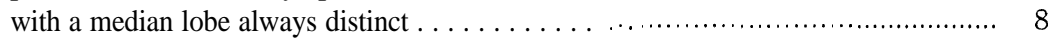

3. Anterior coxal cavities closed behind ...................................... Galeruca Anterior coxal cavities open behind ......................................... 4

4, Seta-bearing pore situated on summit of anterior corner of pronotum, tarsal claws bifid or appendiculate, but not differing between different sexes

S\&a-bearing pore not situated on summit of anterior corner of pronotum, but lateral border near to anterior corner, tarsal claws bifid in male but appendiculate in female ............................................ Apophylia

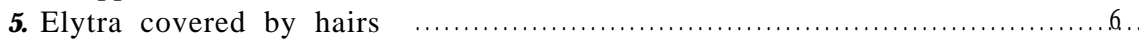

Dorsal surface entirely glabrous ................................... Lochmaea

6. Elytral epipleurae distinct at least on basal $1 / 2$, lateral border of pronotum

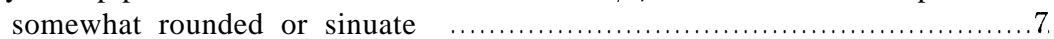

Elytral epipleurae distinct only on basal $1 / 4$ or less; pronotum subquadrate, antennae slender, with second joint elongate but $1 / 3$ as long as third

Chujoa

1) Partly supported by a grant from Japan Society, New York City, through

B. P. Bishop Museum, Honolulu, Hawaii, U. S. A.

2) Contribution Ser. 2, no. 210, Entomological Laboratory, Kyushu University.

3) Hikosan Biological Laboratory, Faculty of Agriculture, Kyushu University. 
7. Disc of pronotum with a large glabrous space at middle ........... Galerucella Disc of fpronotum entirely covered with hairs, but in some cases anterior and lateral margins glabrous ................................................. Pyrrhalta

8. Tarsal claws bifid, anterior coxal cavities opened behind .......................... 9 Tarsal claws appendiculate or simple ..................................................... 11

9. Pronotum without a transverse impression, disc evenly convex.. ................ .10 Pronotum with a transverse impression, sometimes obsolate at middle .........

Aulacophora

10. Body very large and short oval, sides strongly round, elytral epipleurae wide, inferior, recurved basally ...................................................... Oides

Body oblong, somewhat parallel-sided ; epipleurae of elytra normal, relatively narrow and simple

Clerotilia

11. Anterior coxal cavities opened or half opened behind …...................... 12

Anterior coxal cavities closed behind ....................................................... 29

12. Posterior tibiae without a spine at apex ............................................. 13

Middle and posterior tibiae with a spine at apex ................................. 20

13. Anterior and posterior margins of pronotum immarginate …................... 14

Posterior margin of pronotum marginate ............................................. 16

14. Elytra without longitudinal carinae ................................................... 15

Elytra with two pairs of distinct longitudinal carinae ................ Japonitata

15. Pronotum distinctly wider than long; basal margin of elytra without any tuberculation ........................................................................... Euliroetis

Pronotum almost as long as wide, basal margin of elytra with a pair of tuberculations ............................................................... Cerophysella

16. Anterior margin of pronotum immarginate ........................................ 17

Anterior and posterior margins marginate ….................................... 19

17. Elytra without distinct costae at sides .............................................. 18

Elytra with one or two, in some cases three, pairs of longitudinal carinae

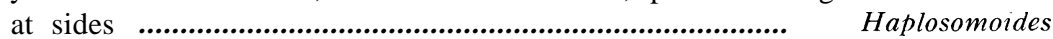

18. Gena very narrower than transverse diameter of eye, frons not so different in both sexes, in male third to four antennal joints reflexed..

Taumacera

Gena almost as long as transverse diameter of eye, in male frons with a pair of large impressions and with a cylindrical process between antennal sockets, antennae almost same in both sexes .......................... Fleutiauxia

19. Elytral epipleurae rather broad in base, gradually narrowed towards apex ...

Elytral epipleurae narrow even in base ....................................... Cneorane

20. Basal margin of pronotum margined; pronotum without a transverse impression, in some cases with feeble impressions at sides ............................. 21

Basal margin of pronotum immarginate; pronotum with a distinct transverse impression ................................................................................. Paridea

21. First joint of posterior tarsi shorter than, or subequal to, following two joints combined ; anterior margin of pronotum marginate ..................22

First joint of posterior tarsi distinctly longer than following two joints combined ................................................................................... 26

22. Body ovate, very large, convex, pronotum more than twice as wide as long Morphosphaera 
Body ovate or oblong ovate, sometime parallel-sided, moderately or scarcely convex; pronotum less than twice as wide as long ....................... 23

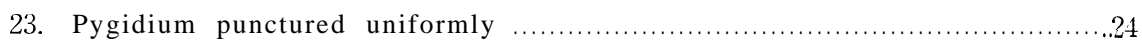

Basal 1/2 of pygidium shiny, glabrous, finely shagreened, apical $1 / 2$ densely punctured, pubescent; lateral margin of elytra visible from above, body oval, dilated posteriorly, tibiae carinate and finely grooved above

Agelastica

24. Third antennal joint as long as, or $11 / 2$ times as long as second ............

Third antennal joint almost, or more than twice as long as second, pygidium uniformly punctate throughout, external margin of elytra not clearly visible throughout from above, oblong-oval, weakly broadened posteriorly ; tibiae not distinctly carinate ...................................... Luperus

25. Prosternal process elevated between coxal cavities, separating them at least anteriorly ; apices of epimera distinct, not extending to infra-coxal lobe; coxal cavities opened or partly opened .......................... Exosoma Prosternal process narrow and not elevated between coxal cavities and not separating them ; apices of epimera distinct ; coxal cavities opened.....

Calomicrus

25. Dorsal surface glabrous or elytra sparsely covered with short hairs .......27

Dorsal surface thickly covered with fine hairs, densely and finely punctate, elytral epipleurae narrowed near middle ..................... Hesperomorpha

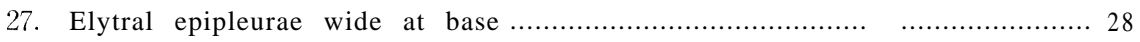

Elytral epipleurae narrow, feebly and gradually narrowed from base to apex; pronotum transversely rectangular with straight sides and with distinct sublateral depression, hind femora slightly thickened .......... Stenoluperus

28. Frontal tubercles transverse, with anterior angles short; apex of frontal carina inserted between these angles or confluent with them; gena short; antennal insertions at middle of eye; prothorax generally with a transverse setigerous pore a short distance from anterior angle of prothorax; hind tibial spine longer than width of apex of tibiae ..................... A trachya

Frontal tubercles elongate-triangular with anterior angles acute, inserted between antennal insertions and separated by a deep groove; gena slightly shorter than smaller diameter of eye; antennal insertions situated just behind level of anterior borders of eyes; prothorax not broader than long; setigerous pore set back $1 / 5$ to $1 / 6$ length of prothorax from anterior angle; hind tibial spine not longer than width of apex of tibiae..... Paralupcrodes

29. First joint of posterior tarsi shorter than two preceding joints combined......

First joint of posterior tarsi longer than two preceding joints combined ......

30. Basal border of pronotum not margined except near side .................... 31

Basal border of pronotum entirely margined .............................. 32

31. Pronotum with a pair of distinct impressions laterally ............. Sermylassa

Pronotum without a pair of distinct impression laterally ............. Hamushia

32. Posterior tibiae with a single spine at apex; pronotum with a distinct depression laterally ; body oblong ................................... Theopea

Posterior tibiae with many short spines at apex, pronotum without deep depression but some times feebly depressed laterally; body oval 
33. Punctures of elytra distinctly 'and confusedly impressed; pronotum with a transverse furrow which is narrow and runs more than $3 / 4$ width of pronotum Agelasa

Punctures of elytra partly or largely arranged in longitudinal rows; pronotum with or without a pair of depressions Gallerucida

\section{Genus Galeruca Geoffroy}

Galeruca Geoff r., 1762, Hist. Ins. 1: 251-Latreille, 1810, Considerations Generales, Paris, 432 (type : Chrysomela tanaceti Linn.).-Weise, 1886, Ins. Deutschl. 6 (4): 578, 637.-Reitter, 1903, Wien. Ent. Ztg. 22: 133.-Maulik, 1936, Fauna India, Galeruc., 97.-Ogloblin, 1936, Fauna USSR 26, 1: 32, 367, 377.-Gressitt \& Kimoto, 1963, Pac. Ins. Man. 1B: 391, 398.

Adimonia Laicharting, 1781, Verz. Tyrol. Ins., 190.- Chapuis, 1875, Gen. Col.11: 220 .

\section{Key to Japanese species of $\mathrm{G}$ al eruca}

1. Anterior corner of pronotum distinctly angulate............................. 2

Anterior corner of pronotum not angulate but widely rounded; length 11.0 to $12.2 \mathrm{~mm}$

cxtense

2. Lateral margins of pronotum deeply sulcated at anterior half; antennae rather robust, fifth joint distinctly shorter than twice as long as wide; length 9.0 $\mathrm{mm}$ spectabilis

Lateral margins of pronotum not or feebly depressed at anterior half; antennae rather slender, fifth joint about three times as long as wide; length IO-11 $\mathrm{mm}$ dah li japonica

\section{Galeruca ex tensa Motschulsky}

Galeruca extenisa Motschulsky, 1861, Etud. Ent. 10: 22 (Japan)--- Chû jô \& Kimoto, 1961, Pac. Ins. 3 (1): 162 (Japan).-Gressitt \& Kimoto, 1963, Pac. Ins. Mon. 1B: 399, 401 (Korea, NE China, SE Siberia).

Galeruca bang-haasi Weise, 1894, Deutsche Ent. Zeitschr. 1894: 168 (Japan : Yokohama ;ZMB).-Oglobin, 1936, Fauna USSR 26, 1: 43, 379, fig. 14b (Ussuri, Manchuria, Japan).-- Chû jô \& Kimoto, 1961, Pac. Ins. 3 (1): 162 (Japan).-Gressitt \& Kimoto, 1963, Pac. Ins. Mon. 1B: 399, 401 (synonymized).

Distribution: SE Siberia, Korea, Manchuria, Japan (3 Kyushu, Honshu, Hokkaido). Naga 32 0: Kamikochi (1 ex., 27. Aug. 1913, M. Suzuki leg.).

Hosts: Allium spp. (after Chûjô \& Kimoto, 1961).

\section{Galeruca spectabilis Faldermann}

Galenuca spectabilis Fald., 1837, Soc. Nat. Moscou, Nouv. Mem. 5: 326, pl. 12, fig. 4 (S. Rossia).--Reitter, 1903, Wien. Ent. Ztg. 22 :136.-Ogloblin, 1936, Fauna USSR 26, 1: 41, 378 (spectabilis and spectabilis orientalis : S. Rossia, Turkey, Iran, Syria). -Gressitt \& Kimoto, 1963, Pac. Ins. Mon. 1B: 399, 403 (Turkey, Syria, Iran, S. Russia, China, Japan).

Galeruca extensa : Chûjô \& Kimoto, 1961, Pac. Ins. 3 (1) : 162 (Japan).

Distribution: Turkey, Syria, Iran, S. Russia, China, Japan (Honshu). 
Yananashi: Masutomi (1 ex., 26-29. July. 1957, S. Miyamoto leg.). Futushima: Nukemizu, Narahara T, Minamiaizu-gun (1 ex., 5. July. 1947, Y. Kurosawa leg.).

\section{Galeruca dahli japonica Weise}

Galcruca dahli var. japonica Weise, 1894, Dtsche Ent. Ztschr. 1894: 168 (Japan: Yokohama; ZMB).-Ogloblin, 1936, Fauna USSR 26, 1: 51, 381 (Japan).-Chûjô \& Kimoto, 1961, Pac. Ins. 3 (1): 162 (Japan).

Distribution: Japan (Honshu, Hokkaido).

Nagano: Karuizawa. Yamanashi: Masutomi. Saitama: Urawa City. Tokyo: Kamisuwa in Okutama. Hokkaido: Engaru in Abashiri ; Shikaribetsu in Rubeshibe; Ponkikin in Abashiri ; Yufutsu ; Ashoro in Tokachi; Obihiro City.

Hosts: Cirsium spp.

\section{Genus Apophylia Duponchel \& Chevrolat}

Apophylia $h p$. \& Chev., 1842, in d'Orbigny, 1842, Dict. Univ. d'Hist. Nat. 2: 31.Allard, 1889, Soc. Ent. Belg., Bull. 33: lxxi.-Maulik, 1936, Fauna India, Galeruc., 78 (type : Apophylia chloroptera).-Ogloblin, 1936, Fauna USSR 26, 1: 138, 369.Chûjô 1962, Phil. Jour. Sci. 91 (1- 2): 13, 18.--Gressitt \& Kimoto, 1963, Pac. Ins. Mon. 1B: 391, 426.

Malaxia Fairmaire, 1878, Soc. Ent. France, Ann. ser. 5, $8: 139$ (type : M. flavovirens Fairm.).-Allard, 1889, Soc. Ent. Belg., Bull. 33: 1xxx.

Glyptolus Jacoby, 1884, Leyden Mus., Notes 6: 62 (type: G. viridis Jac.; Sumatra).

Glcrucesthis Weise, 1896, Dtsche Ent. Ztschr. 1896 : 296 (type: Auchenia? thalassina Fald.).

\section{Key to Japanese species of Apophylia}

1. Legs blackish

Legs almost entirely yellowish brown; black, elytra green; antennae entirely

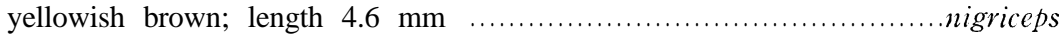

2. Prothorax reddish brown; head, except clypeus, stained with reddish brown, antennae and legs black, elytra green; length $6.2-9.0 \mathrm{~mm}$.......... elongata

Prothorax blackish; black, basal joints of antennae and tibiae and apical parts of femora somewhat pale, elytra green $; 4.2--5.0 \mathrm{~mm}$.. .......viridipennis

\section{Apophylia nigriceps Laboissière}

Apophylia nigriccps Lab., 1927, Soc. Ent. France, Ann. 96 :62 (Yunnan-Fou).-Chûjô, 1962, Phil. Jour. Sci. 91 (1/2): 21 (Yunnan, Formosa).-Gressitt \& Kimoto, 1963, Pac. Ins. Mon. 1B: 427, 431 (S. China).

This is the first record of the species from Japan.

Distribution: S. China, Taiwan, Japan (Kyushu).

Oita: Mt. Sobo (I ex., 27. July 1953, S. Kimoto leg.). 


\section{Apophylia elongata (Jacoby) (Fig. 1)}

Malaxia elongata Jec., 1895, Entomolog. 29: 8 (Loochoos: Oshima).

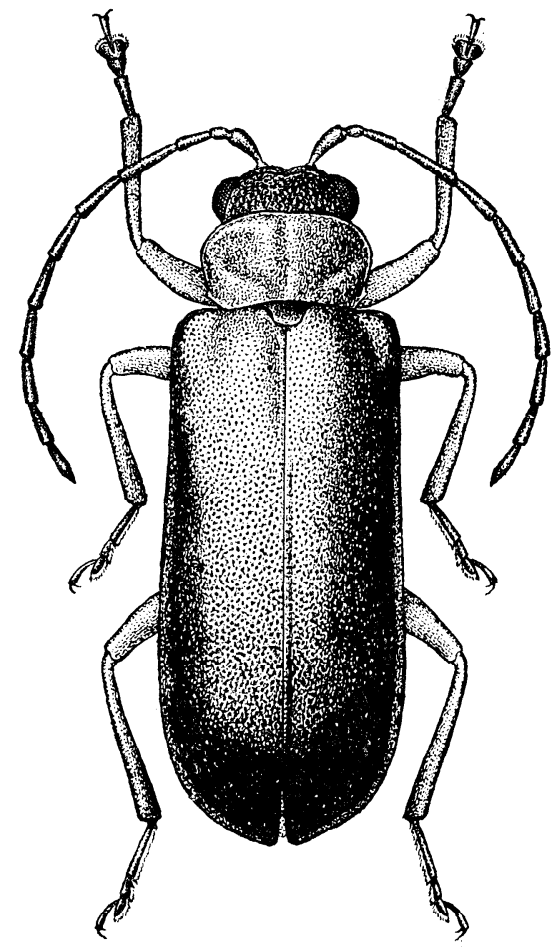

Fig. 1. Apophylia elongata (Jacoby).

Apophylia elongata : Chû jô \& $\mathrm{K}$ i m o t o, 1961, Pac. Ins. 3 (1): 157 (Ryukyu Is.).

Distribution: Ryukyu Is . (AmamiOshima, Okinawa Is.).

Okinawa group: Okinawa Is. (4 exs., 2 -4. Apr. 1955, T. Takara leg. ; I ex., June. 195-1, G. E. Bohart leg.). Amami group: Amami-Oshima (after Nakane \& Kimoto, 1959, 1961).

\section{Apophylia viridipennis (Jacoby)}

Galenucclla viridipcnnis Jacoby, 1885 , 2001 . Soc. Lond., Proc. 1885 : 744, pl. 46, fig. 9 (Japan: Kurigahara, Wadatoge; $\mathrm{BM})$.

Apophylia viridipennis: Ogloblin, 1936, Fauna USSR 26, 1:142, 393 (Japan).-Chûjô \& Kimoto, 1961, Pac. Ins. 3(1): 157 (Japan).

Distribution: Japan (Honshu).

Yamanashi: Kiyosato (4 exs., 29-31. July. 1957, S. Miyamoto leg.); Shosenkyo (1 es., 22. July. 1936, H. Kamiya leg.).

\section{Genus Lochmaea Weise}

Lochmaea Ws., 1883, Dtsche Ent. Ztschr. 27 : 316 (type :Chrysomela capreae L.; Europe); 1886, Ins. Deutsch1. 6 (4): 575, 610.--Ogloblin, 1936, Fauna USSR 26, 1: 82, 369, 38-L --Gressitt \& Kimoto, 1963, Pac. Ins. Mon. 1B: 392, 416.

\section{Lochmaea capreae (Linnaeus)}

Ch rysomelacaprecie L., 1758, Syst. Nat. ed. 10 : 376 (Europe).

Adimonin capreae: Motschulsky, 1866, Soc. Imp. Nat. Moscou, Bull. 39 (1): 175 (Japan).

Lochmaca capreae: Ogloblin, 1936, Fauna USSR 26, 1: 87, 369, 385 (E. Siberia, Manchuria, China, Korea, Japan).-Gressitt \& Kimoto, 1963, Pac. Ins. Mon. 1B: 416 (Europe, Siberia, S. China, Korea, Japan).

Loch maea capreae cribra ta: Chû jô \& Kimoto, 1961, Pac. Ins. 3 (1) : 165 (E. Siberia, Manchuria, China, Korea, Japan).

Oblong oval; pronotum with a pair of lateral and one antero-madian and one postero-median depressions, surface rather closely and distinctly punctate ; elytra distinctly and more closely punctate than in pronotum; black; pronotum and elytra yellowish brown; scutellum dark reddish brown ; length $5.0-6.0 \mathrm{~mm}$..

Distribution: Europe, Siberia, N. China, Korea, Japan (Hokkaido, Honshu). 
Ishikawa: Hakusan. Nasano:Shirahone; Shimashima. Gumma: Sampei Pass ; Numata City. Tochigi : Nikkc. Aomori: Yunomata in Shimokita Pen. Hokkaido: Ashoro, Nukabira in Takachi ; Yukomanbetsu at Mt. Daisetsu; Piuca in Kamikawa; Engaru in Abashiri ; Nibushi, Kuccharo at Akan Prov.

Hosts: Populus spp., Salix spp. (after Chûjô \& Kimoto, 1961).

\section{Genus Chujoa Gressitt \& Kimoto}

Chiijoa Gressitt \& Kimoto, 1963, Pac. Ins. Mon. 1B: 392, 437 (type : Atysa uetsukii Chû jô, 1954 ; Japan).

\section{Chujoa uetsukii (Chûjô)}

Atysa uctsukii Chû jô, 1954, Mushi 26 (1): 2, pl. 1, fig. 1 (Japan : Chuka-mura in Okayama Pref ; Chuso).-Chûjô \& Kimoto, 1961, Pac. Ins. 3 (1) : 158 (Japan).

Chuljoa uetsukii : Gressitt \& Kimoto, 1963, Pac. Ins. Mon. 1B: 437 (S. Japan).

Oblong, subparallel-sided ; closely covered with fine pubescence; antennae slender, long, about $3 / 4$ as long as length of body; pronotum subquadrate, with a pair of lateral depressions and a longitudinal furrow; reddish brown with antennae, except basal joints, darker than the other parts of body; length $5.8-8.0 \mathrm{~mm}$.

Distribution: Japan (Honshu, Shikoku, Kyushu).

Oita: Mt. Sobo (8 exs., 24. July.-4. Aug. 1955, H. Kamiya leg.). Kochi :Nishigoya at Mt. Ishizuchi (1 ex., 31. July. 1952, K. Morimoto leg.).

Host : Faguscrenata (after Chûjô \& Kimoto, 1961).

\section{Genus Galerucella Crotch}

Galcrucella Crotch, 1873, Acad. Sci. Philad., Proc. 1873: 55.-Weise, 1886, Ins. Deutschl. 6 (4): 575, 622.-Maulik, 1936, Fauna India, Galeruc., 214 (designated Chrysomela nymphaea L. as type) (part).-Chûjô, 1962, Phil. Jour. Sci. 91 (1-Z) : 13, 37, 39.-Gressitt\& Kimoto, 1963, Pac. Ins. Mon. 1B: 392, 468.

Hydrogaleruca Laboissiere, 1922, Rev. 2001. Afr. 10 : 32 (type :Chrysomelanymphaea L.; Europe).-Ogloblin, 1936, Fauna USSR 26, 1: 119, 388 (as a subgenus of Galerucella).

\section{Key to Japanese species of Galerucella}

Sutural angles of elytra obtuse, rounded; antennae rather slender, seventh to tenth joints more than, or nearly, twice as long as wide ; reddish brown; each elytron with an ill-defined submarginal pitchy stripe, which is starting from humerus and running towards apex; antennae black with basal joints paler; vertex and meso- and metathorax, in some cases some parts of abdomen also, blackish ; length $3.7-5.2 \mathrm{~mm} \mathrm{.................................................} \mathrm{grisescens}$

Sutural angles of elytra subquadrate; antennae rather robust, seventh to tenth joints less than, or nearly, $1 / 2$ times as long as wide; vertex, antennae, pronotum, meso- and metathorax and elytra largely black, anterior half of head, anterior margin and ventral surface of thorax, lateral margins of elytra and abdomen reddish brown; legs reddish brown with tarsi and outer surface of

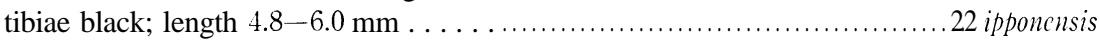




\section{Galerucella nipponensis (Laboissière)}

Galeruca sagit tariac: Baly, 1874, Ent. Soc. London, Trans. 1874:178 (Japan: Hiogo).

Hydrogalenucanipponensis Lab., Jan. 1, 1922, Rev. Zool. Afrique 10: 120 nota (Japan ). —Chûjồ \& Kimoto, 1961, Pac. Ins. 3 (1):164 (Japan, Korea, SE Siberia).

Galerucella paludosa Weise, Oct. 12, 1922, Tijdschr. Ent. 65 : 68 (Japan :Kioto).

Galenucella (Hydrogaleruca) nipponensis : Ogloblin, 1936, Fauna USSR 26, 1: 126 , 389, fig. 52a, 54 (SE Siberia, Korea, Japan).

Galcrucella nipponensis : Gressitt \& Kimoto, 1963, Pac. Ins. Mon. 1B: 468, 470 (Japan, Korea, SE Siberia).

Distribution: Korea, SE Siberia, Japan (Honshu, Shikoku, Kyushu).

Fukuoka: Kokubu-cho in Kurume City; Shikano-shima in Kasuya-gun ; Najima, Kashii in Fukuoka City. Miyazaki: Aoshima.

Hosts: Brasenia Schreberi ; Ludvigia ovalis ; Lycopus lucidus ; Trapa japonica (after Chûjò \& Kimoto, 1961).

\section{Galerucella grisescens (Joannis)}

Galcruca grisescens Joannis, 1866, Abeille 3 : 98 (Sicily).

Galleruca vittaticollis Baly, 1874, Ent. Soc.Lond., Trans. 1873 : 178 (Japan : Nagasaki, Yokohama ; BM).

Galleruca distincta Baly, 1874, t.c. (Japan : Nagasaki ; BM).

Galerucella (Hydrogaleruca) grisescens : Ogloblin, 1936, Fauna USSR 26,1:120, 389 (Japan).

Hydrogaleruca distincta subsp. yakushimana Nakane, 1958, Saikyo Univ., Sci. Rep. 2 (5): A308 (Japan: Miyanoura in Yakushima ; NSM).

Hydrogaleruca vittaticollis : Chûjô \& Kimoto, 1961, Pac. Ins. 3 (1):16j (Japan, Korea, Manchuria, N. China, E. Siberia, Sachalin).

Galerucella grisescens distincta: Chûjô, 1962, Phil. Jour. Sci. 91 (1-2) : 40(Japan, Korea, China, Siberia, Formosa).

Galcrucella grisescens: Gressitt \& Kimoto, 1963, Pac. Ins. Mon. 1B:468 (Europe, Siberia, China).

Distribution: Taiwan, Japan (Hokkaido, Honshu, Shikoku, Kyushu, Tsushima, Yakushima), Ryukyu Is. (Ishigaki), Korea, Manchuria, N. China, E. Siberia, Sachalin, Europe.

Sak ishima group: Ishigaki Is. (2 exs., 20-30. Dec. 1952, G. E. Bohart leg.).

Fukuoka: Mt. Kora in Kurume City; Mt. Wakasugi ; Mt. Hiko; Fukuoka City :

Kokura City ; Tashiro in Yame-gun. Kumamoto: Mt. Ichifusa. Miyazaki: Aoshima; Hyuga Line ; Kiyotake in Miyazaki-gun. Kagoshima: Sata-misaki; Shiroyama in Kagoshima City. Kochi: Jinzenji in Kochi City. Nagano: Karuizawa. Hokkaido: Engaru in Abashiri ; Aizankei at Mt. Daisetsu.

Hosts: Polygonum spp. ; Rumex spp. ; Fragaria chilocnsis var. ananassa (after Chûjô \& Kimoto, 1961).

\section{Genus Pyrrhalta Joannis}

Pyrrhalta Joannis, 1866, Abeille 3: 82 (type :Galeruca viburni Paykull; Europe).Weise, 1886, Ins. Deutschl. 6 (4): 621.-Ogloblin, 1936, Fauna USSR 26, 1: 97, 385. -Chûjô, 1962, Phil. Jour. Sci. 91 (1-2): 37.-Gressitt \& Kimoto, 1963, Pac. Ins. Mon. 1B: 392, 438. 
Hoplostines Blackburn, 1890, Linn. Soc. N. S. Wales, Proc. ser. 2, $5: 361$ (type : Hoplostinesviridipennis Blackburn, 1890).

Tricholochmaea Laboissière, 1932, Mus. Nat. Hist. Nat. Paris, Bull. ser. 2, 4: 963 (type : L. indica Lab., India).-Ogloblin, 1936, Fauna USSR 26, 1: 91, 385 (as a subgenus of Lochmaea).

Xanthogaleruca Lab., 1934, Soc. Ent. France, Ann. 103 : 29, 67 (type :luteola Miiller ; Europe).-Ogloblin, 1936, Fauna USSR 26, 1: 100, 386.-Chûjô, 1962, Phil. Jour. Sci. 91 (1-2): 37, 38.

Galerucella: Maulik, 1936, Fauna India, Galeruc., 214 (part).-Oglobin, 1936, Fauna USSR 26, 1: 112, 387.

Clitena: Ogloblin, 1936, Fauna USSR 26, 1: 129, 369, 391..

Isshikia Chûjô, 1961, Ent. Lab., Univ. Osaka Pref., Pub. 6: 87 (type : I. isshlikii Chûjô, 1961; Ryukyu Is.) (as a subgenus of Galeruca). New S yn ony my

Neogalerucella Chûjô, 1962, Phil. Jour. Sci. 91 (1-2) : 37, 38 (type : Chrysomelatenella Linnaeus, 1761; Europe). New Synonymy

\section{Key to Japanese species of Pyrrhalta}

1. Antennae rather robust, fifth to tenth almost, or shorter than, twice as long as wide

Antennae rather slender, fifth to tenth almost, or more than three times as

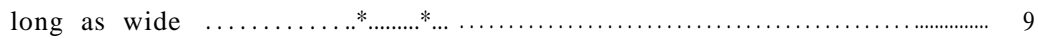

2. Lateral margin of elytra with a distinct longitudinal convexity which is ex-

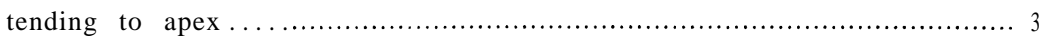

Lateral margin of elytra without distinct longitudinal convexity which is ex-

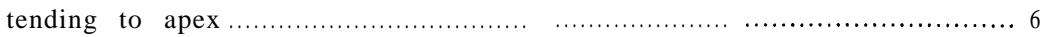

3. Elytral epipleurae distinct on more than basal $3 / 4$. ............................... 4

Elytral epipleurae distinct on basal $2 / 3$; brown, vertical area of vertex, middle of pronotum, scutellum, tibiae, tarsi apico-dorsal surface of femora black or blackish ; antennae almost entirely_ black ; length 5.2-5.3 $\mathrm{mm}$

kawashimai

4. Abdomen yellowish or reddish; basal margin of pronotum obliquely truncate

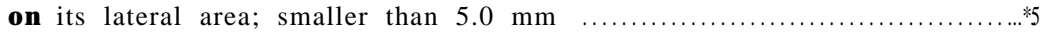

Abdomen entirely black; basal margin of pronotum emarginated on its lateral area; head black with frontal tubercles dark reddish, antennae black with one or two basal joints pale; pronotum, scutellum and elytra reddish brown, with basal area of scutellum infuscate; ventral surface and legs black with tibiae and tarsi reddish) brown; length 5.2-6.0 $\mathrm{mm}$........ takeii

5 Elytral epipleurae distinct until apex; dorsal surface entirely yellowish brown ; antennae, especially dorsal surface dark brown ; length $4.0 \mathrm{~mm}$. . . . . konishii

Elytral epipleurae not distinct at apical area; dorsal surface largely reddish brown to brown; scutellum black, in many cases pronotum black on middle or entirely black; head, meso- and metathorax and legs variable in coloration, generally ground color of those reddish but in many cases stained with black in various degrees; antennae usually black, in some cases four or five basal joints pale; length $3.0-5.0 \mathrm{~mm}$........................ semifulva

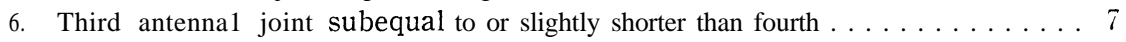
Third antennal joint much longer than fourth 
7. Elytra dark reddish brown with sutural and lateral margins black ; underside black; legs, lower part of head and thorax dark reddish brown ; thorax with three black spots; length $4.2 \mathrm{~mm}$

nigromarginata

Elytra dark reddish brown, with a black humeral spot and a lateral stripe situated on same level with humerus; brown, metathorax and abdomen largely black, head with a black spot on vertex, frontal tubercles black; antennae black; prothorax with a large black spot on middle and a pair of broad black stripes situated closely to lateral margin of prothorax; legs blackish, femora and basal part of tibiae reddish brown ; length $6.5 \mathrm{~mm}$...

maculicollis

8. Elytral epipleurae not distinct on their extremities; brown, vertical area of vertex, middle of pronotum, scutellum, humeri, meso- and metathorax, and entire first (visible) to third and middle of fourth segments blackish ; antennae black with basal parts of each joint more or less brownish; length 5.0 $\mathrm{mm}^{*}$

.lineola

Elytral epipleurae distinct on their extremities; brown, vertical area of vertex, antennae, except two or three basal joints pale, middle of pronotum, scutellum, a broad band running from humerus to subapical area, underside of meso- and metathorax and first to third abdominal segments blackish; length $4.2 \mathrm{~mm}^{*}$ (typical form); in some cases brown, antennae except three or four basal joints pale, humeri and underside of meso- and metathorax blackish ; length $4.0 \mathrm{~mm}$ (lythri type) ...........................calmariensis

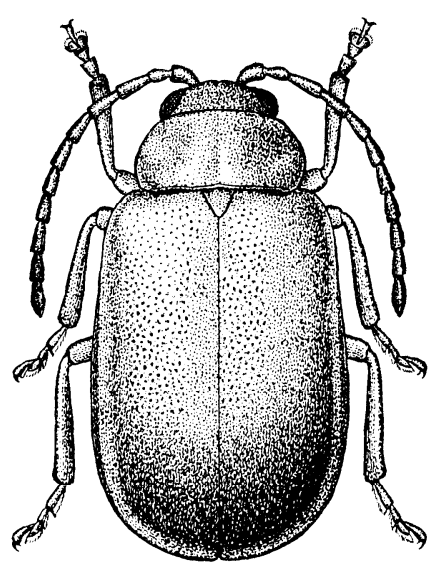

a

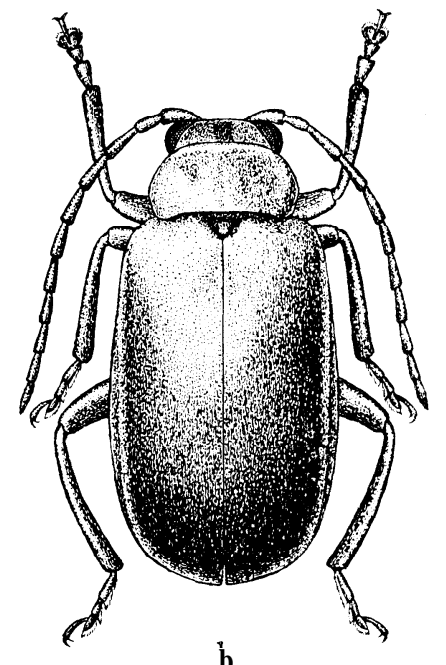

b

Fig. 2. a, Pyrrhaltakonishii Kimoto; b, P. yasumatsui n. sp.

9. Apex of scutellum truncate and trapezoidal in form; large in size, larger than $5.5 \mathrm{~mm}$

Apex of scutellum rounded; subtriangular ; brown, antennae dark reddish brown, except three or four basal joints pale; in many cases elytra green-

* These descriptions were prepared by the specimens collected in Germany. 
ish ; length $4.0-4.8 \mathrm{~mm}$

yasumatsui

10. Elytral punctures very minute and sparsely impressed . ........................11

Elytral punctures rather strongly and closely impressed .................... 13

11. Elytral epipleurae gradually narrowed towards apex …...................... 12

Elytral epipleurae not narrowed towards apex but subequal in width between preapical and basal areas; yellowish brown ; apical part of femora, dorsal surface of tibiae and tarsi infuscate in various degrees; antennae blackish with basal $1 / 4$ to $1 / 6$ of each joint pale; a broad stripe situated closely to lateral margin of prothorax, in some cases a small spot on middle of base also, and a spot on humeri of elytra black ; length $7.0-8.2 \mathrm{~mm} . . . \ldots$. esakii

12. Third antennal joint more than twice as long as second, a broad stripe situated closely to lateral margin of prothorax, a small spot on middle of base and a spot on humeri of elytra black; length $5.8-6.8 \mathrm{~mm} \ldots \ldots \ldots \ldots \ldots$

humeralis

Third antennal joint one and half times as long as second, a broad stripe situated closely to lateral margin, a small basal spot on middle and a spot on humeri of elytra black; length $7.2-8.8 \mathrm{~mm} \ldots \ldots \ldots \ldots \ldots \ldots$ annulicornis

13. Elytra entirely fulvous ......................................................... 14

Elytra dark green with cupreous luster; black, lower part of head, thorax, basal $3 / 4$ of femora and abdomen yellowish brown; thorax with three blackish spots; length $8.0 \mathrm{~mm}$....................................... fuscipennis

14. Elytra with a distinct longitudinal costa along lateral margin ............... Elytra without a longitudinal costa along lateral margin; yellowish brown; antennae and tibiae blackish ; length $7.5-8.0 \mathrm{~mm}$...................... tibialis

15. Elytra ruglosely punctured but those punctures impressed rather shallowly; black, basal part of pronotum and entire elytra yellowish brown; length

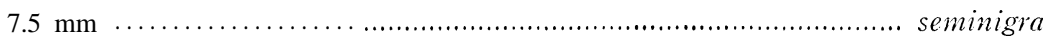

Elytra distinctly and closely punctured but a diameter of each puncture almost as wide as their interstices, and those punctures rather deeply impressed; yellowish to reddish brown; antennae, tibiae, tarsi, apex of femora, a marking on vertex, lateral area of pronotum together with a marking before scutellum, and elytral humeri black; length 7.0-8.0 $\mathrm{mm} \ldots$

issh ikii

\section{Pyrrhalta kawashimai n. sp.}

Brown; vertical area of vertex, middle of pronotum, scutellum, tibiae, tarsi and apico-dorsal surface of femora black or blackish; antennae almost entirely black.

Vertex rugosely punctate and covered with fine pubescence; frontal tubercles subquadrate, distinctly raised; inter-antennal space narrowly carinate. Antennae almost $2 / 3$ as long as length of body, first large and club-shaped; second short, third one and half times as long as second, fourth one and a quarter times as long as third, fourth to seventh subequal in length and shape to each other, eighth to tenth subequal in length and shape to each other, eleventh one and half times as long as tenth and pointed at apex. Pronotum transverse, twice as wide as long, anterior margin almost straight, lateral margin rounded, widest almost at middle, basal margin slightly emarginate at middle and turned obliquo-forward 15 at lateral area, anterior and posterior corners each with a seta-bearing pore; 
surface covered with fine pubescence, concaved as a whole, and more deeply concaved on middle and on either side. Scutellum trapezoidal, densely covered with fine pubescence. Elytra broader than prothorax at base, closely and rather distinctly punctured ; epipleurae narrowed towards apex and distinct only on basal $2 / 3$.

Length $5.2-5.3 \mathrm{~mm}$.

Holo type: Yugawara, Kanagawa Pref. (2. May. 1955, K. Kawashima leg.) (Entomological Laboratory, Kyushu University).

Paratopotype: 1 ex., same as the holotype.

This species is characteristic in having the elytral epipleurae which are distinct on basal $2 / 3$.

\section{Pyrrhalta takeii (Chûjô) New Combination (Fig. 3b)}

Lochmaea (Tricholochmaea) takeii Chûjô, 1950, Kontyû 18 (5): 114, 1 fig. (Japan : Numata-cho in Gumma Pref.; CHUJ०) .

Tricholochmaea takeii : Chûjô \& Kimoto, 1961, Pac. Ins. 3 (1) : 169 (Japan).

Distribution: Japan (Honshu).

Tottori: Hoki-Daisen (1 ex., 24. May. 1954, S. Kimoto leg.).

\section{Pyrrhalta konishii Kimoto (Figs. 2a, 3a)}

Pyrrhalta konishii Kimoto, 1963, Fragm. Col., Kyoto (4): 17 (Maruyama in Hokkaido; $\mathrm{KU})$.

Distribution: Japan (Hokkaido).
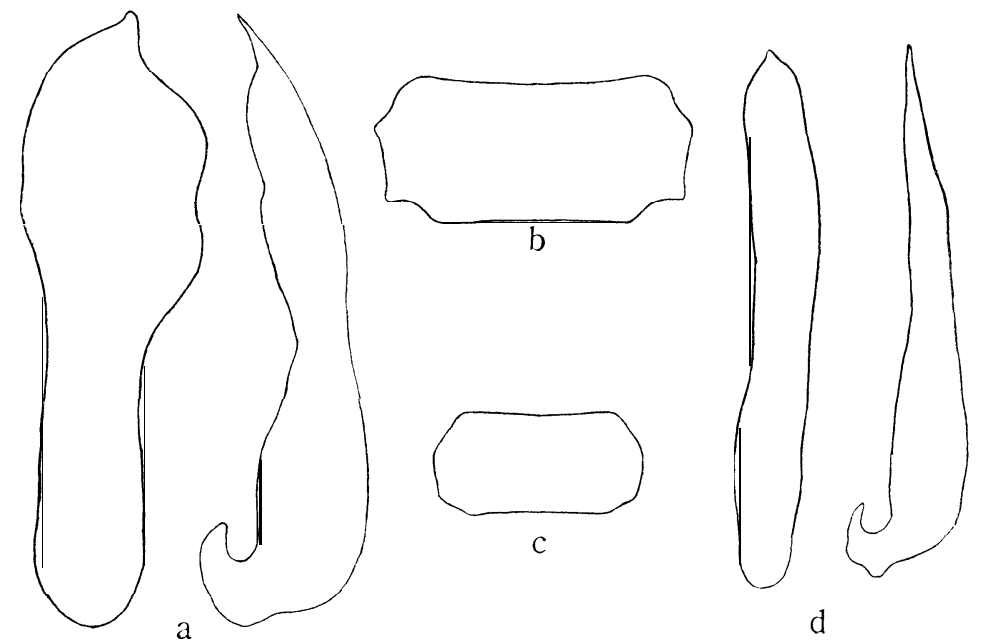

Fig. 3. a and cl, male genitalia, b and c, pronotum : a, Pyrrhaltakonishii Kimoto ; b, P. takeii (Chûjô); c d, P. semifulva (Jacoby). 


\section{Pyrrhalta semifulva (Jacoby) New Combination (Figs. 3c-d)}

Galcrucella semifulva Jacoby, 1885, Zool.Soc. Lond., Proc. 1885 : 745, pl. 46, fig. 11 (Japan: Kiga; BM).

Galcrucella modesta Jacoby, 1885, loc. cit. (Japan : Nikko ; BM).

Lochmaea japonica Weise, 1922, Tijdschr. Ent. 65 : 67 (Japan : Kioto).

Lochmaea (Tricholochmaea) scmifulva: Ogloblin, 1936, Fauna USSR 26, 1: 91, 385,

fig. 38 (E. Siberia, Manchuria, China, Japan).--Chûjô \& Kimoto, 1961, Pac. Ins.

3 (1): 166 (E. Siberia, Manchuria, China, Japan).

The verification of the record of the species from outside of Japan may be required. $P$. limbata Chen was first described as semifulva subsp. limbata but Gressitt \& Kimoto (1963) treated as an independent species in having characteristic male organ among the species group.

Distribution: E. Siberia, Manchuria, Japan (Hokkaido, Honshu, Sado I., Shikoku, Kyushu).

Fukuoka: Nakatashiro, Tashiro in Yame-gun ; Mikazuki-yama in Fukuoka City; Mt. Fukuchi ; Kokura City; Mt. Hiko. Oita : Mt. Sobo. Kagoshima :Shiro-yama in Kagoshima City. Kochi: Jinzenji in Kochi City ; Kuroson. Tokushima : Jinryomura in Myosai-gun. Osaka: Minoo. Nara : Mt. Yoshino; Mt. Kasuga. Wakayama: Koya-san. Fukui: Mt. Murakuni in Takefu City. Nagano : Asama-Onsen ; Wada-toge; Karuizawa. Yamanashi: Shosenkyo. Tochigi : Nikko. 1961).

Hosts: Cherry ;Corylopsis Gotoana ; Sorbus japonica (after Chûjô \& Kimoto,

\section{Pyrrhalta nigromarginata (Jacoby)}

Galerucellanigromarginata Jacoby, 1885, Zool.Soc. Lond., Proc. 1885: 743, pl.46, fig. 10 (Japan ; BM).

Galcrucclla (Xanthogaleruca) nigromarginata: Ogloblin, 1936, Fauna USSR 26, 1:

112, 386 (Japan).-Chû jô \& Kimoto, 1961, Pac. Ins. 3 (1) : 163 (Japan).

Pyrrhalta nigromarginata: Gressitt \& Kimoto, 1963, Pac. Ins. Mon. 1B: 439, 459 (Japan, Hainan Is.).

I have not seen any specimens collected in Japan besides the type. This seems to be a very rare species.

Distribution: Japan, Hainan Is.

\section{Pyrrhalta maculicollis (Motschulsky)}

Galeruca maculicollis Motschulsky, 1853, Etud. Ent. 2: 49 (N. China).-Baly, 1S74, Ent. Soc. Lond., Trans. 1874: 177 (Nagasaki, Yokohama).

Gallerucella (Xanthogaleruca) maculicollis : Oglobin, 1936, Fauna USSR 26, 1: 104, 387, fig. 41 (Siberia, Manchuria, China, Japan).-Chûjô \& Kimoto, 1961, Pac. Ins.

3 (1): 162 (Japan, Korea, Manchuria, N. China, E. Siberia).

Pyrrhalta maculicollis: Gressitt \& Kimoto, 1963, Pac. Ins. Mon. 1B: 439, 457 (SE Siberia, E. China).

Distribution: SE Siberia, E. China, Manchuria, Korea, Japan (Hokkaido, Honshu, Sado I., Shikoku, Kyushu). 
Tokushima: Kamiyama-mura in Myosai-gun. Nagano: Utsukushigahara ; Asama-Onsen. Yamanashi: Atago-yama in Kofu City. Hokkoido : Yubari in Sorachi ; Nibushi at Akan Prov.; Mt. Daisetsu ; Jozankei nr-. Sapporo City; Ashoro in Tokachi; Obihiro City; Sapporo City.

Hosts : Ulmus spp., Zelkova serrata (after Chûjồ \& Kimoto, 1961).

\section{Pyrrhalta lineola (Fabricius) (Fig. 4a)}

Chrysomela lineola F., 1781, Spec. Ins. 1: 149 (Europe).

Galerucella lineola: Ogloblin, 1936, Fauna USSR 26, 1: 114, 388 (Europe to Ussuri). -Chûjo, 1959, Kagawa Univ., Mem. Fac. Lib. Arts \& Educ. 2 (81): 11 (Japan : Rishiri-to, Mt. Tokachidake in rang of Mt. Daisetsu-san Nat. Park in Hokkaido). -Chûjố \& Kimoto, 1961, Pac. Ins. 3 (1) 162 (Palaearctic region, Japan).

Pyrrhalta lineola: Gressitt \& Kimoto, 1963, Pac. Ins. Mon. 1B:442, 455 (Europe, N. Asia, NE China, Sachalin, N. Japan).

The illustration of male aedeagus of the species was prepared by a German specimen.

Distribution: Europe, Siberia, Manchuria, Sachalin, Japan (Hokkaido).

Hosts: Alnus spp.; Corylus spp. ; Salix spp. (after Chûjồ \& Kimoto, 1961).
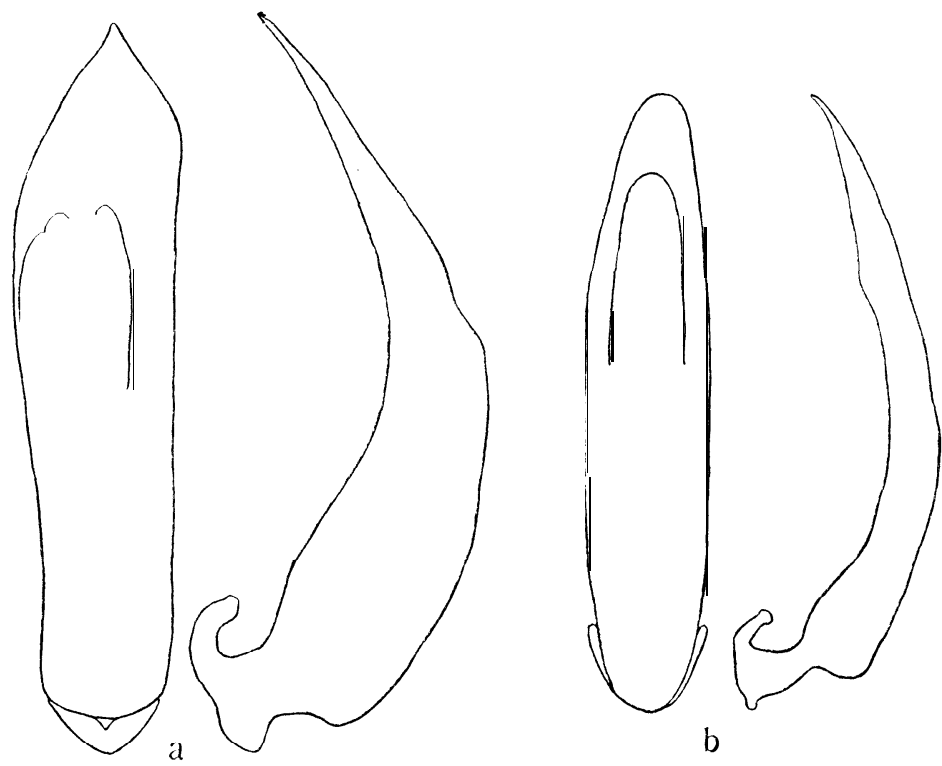

Fig. 4, Male genitalia: a, Pyrrhalta lineola (Fabricius) ; b, P. calmariensis (Linnaeus).

\section{Pyrrhalta calmariensis (Linnaeus) (Fig. 4b)}

Chrysomela calmariensis L., 1767, Syst. Nat. ed. 12: 600 (Europe).

Galerucella lineatipes Takei, 1916, Konchû Sekai, Gifu 20 (226) : 253 (Japan :Gumma Pref.). 
Galcrucclla calmariensis : Ogloblin, 1936, Fauna USSR 26, 1: 115, 388, figs. 46, 47b, 48.-Chûjô, 1956, Kagawa Univ., Mem. Fac. Lib. Arts \& Educ. 2 (31): 8, fig. 4 (Japan : Odayama and Wakamatsushi in Fukushima Pref.).-Chû jô \& Kimoto, 1961, Pac. Ins. 3 (1): 162 (Palaearctic region, Japan).

Pyrrhalta calmariensis: Gressitt \& Kimoto, 1963, Pac. Ins. Mon. 1B:447 (Europe, N. China).

Distribution: Palaearctic region ; Japan (Honshu, Hokkaido).

Hokkaido: Tomakomai City (2 exs., 5. Aug. 1952, S. Ishii leg.).

Hosts: Tn Europe, Lythrum Salicaria; Stachys palustris.

\section{Pyrrhalta yasumatsui n. sp. (Fig. 2b)}

Brown; antennae dark reddish brown with three or four basal joints pale; elytra in many cases somewhat greenish.

Vertex rugosely punctate and covered with fine pubescence; frontal tubercles convex, subquadrate, separated to each other by a longitudinal groove, interantennal space extremely narrow but carinate. Antennae almost $2 / 3$ as long as body length, first joint long and club-shaped, second slender, about $2 / 3$ of first in length, third long, nearly twice as long as second; fourth slightly shorter than third, fifth slightly shorter than fourth and subequal in. length to first. Thorax transverse, twice as wide as long, anterior margin slightly emarginate, lateral margin widest almost at middle, almost straightly narrowed anteriorly and posteriorly, basal margin slightly emarginate at middle and turned obliquo-forwardly at lateral area, anterior and posterior corners each with a seta-bearing pore, surface rugosely punctate and covered with fine pubescence, longitudinally grooved on middle and strongly depressed on each side. Scutellum triangular, apex rounded, covered with fine pubescence. Elytra broader than thorax at base, parallelsided, lateral margin narrowly marginate, surface closely punctate and closely covered with pubescence ; elytral epipleurae gradually narrowed towards apex.

Length $4.0-4.8 \mathrm{~mm}$.

Distribution : Ryukyu Is. (Okinawa, Amami-Oshima).

Holotype: Okinawa, Ryukyu Is. (7. May. 1958, T. Takara leg.) (Entomological Laboratory, Kyushu University).

Pam types: 3 exs., Okinawa, Ryukyu Is. (3. May. 1958, T. Takara leg.); 1 ex., Yakkachi (Sumiyo-mura), Amami-Oshima (18. July. 1933, T. Esaki \& K. Yasumatsu leg.); 1 ex., Gusuku-Nishinakama (Santarotoge), Amami-Oshima (15. July. 1933, T. Esaki \& K. Yasumatsu leg.).

This species is characteristic in having a rounded apex of scutellum and being small in size.

\section{Pyrrhalta esakii Kimoto}

Pyrrhaltacsakii Kimoto, 1963, Fragm. Col., Kyoto, (4): 17 (Mt. Takao in Tokyo, Shirahone in Nagano Pref., Mt. Yoshino in Nara Pref., Gifu City, Kibune in Osaka, Odaigahara, Hanazono near Kyoto, Katsuragawa near Kyoto; KU).

Distribution: Japan (Honshu),

\section{Pyrrhalta humeralis (Chen)}

Galerucella humeralis Chen, 1942, Notes d'Ent. Chinoise 9: 17 (China). 
Pyrrhalta humeralis: Nakane \& Kimoto, 1961, Kontyû 29 (1) : 21 (Hentona in Okinawa ; Japan).-Gressitt \& Kimoto, 1963, Pac. Ins. Mon. 1B: 439, 451 (China).

Distribution: China, Ryukyu Is. (Okinawa Is.), Japan (Hokkaido, Honshu, Shikoku, Kyushu).

Okinawa group: Okinawa Is. (after Nakane \& Kimoto, 1961).

Fukuoka: Mt. Hiko ; Kokura City. Miyazaki: Miyazaki City ; Aoidake. Tokushima: Jinryo-mura in Myosai-gun. Okayama: Kamo-cho in Tomata-gun. Fukui: Mt. Murakuni in Takefu City. Nagano :Ontake in Kiso-Fukushima ; Karuizawa ; Wadatoge. Aomori: Yunomata in Shimokita Pen. Hokkaido: Nukabira in Tokachi ; Mt. Hakodate in Oshima Pen.

Hosts : In China, Viburnum sp., Salix sp. (after Gressitt \& Kimoto, 1963).

\section{Pyrrhalta annulicornis (Baily)}

Galleruca anmulicornis Baly, 1874, Ent. Soc. Lond., Trans. 1874: 177 (Japan: Hiogo ; BM).

Galerucella (Pyrrhalta) viburni annulicornis : Ogloblin, 1936, Fauna USSR 26, 1: 100, 385 (Manchuria, China, Japan).

Pyrrhalta annulicornis : Chûjô \& Kimoto, 1961, Pac. Ins. 3 (1) : 168 (Japan, Ryukyu Is., Korea, N. China, Manchuria, Sachalin).-Gressitt \& Kimoto, 1963, Pac. Ins. Mon. 1B: 439, 445 (Japan, NE China, SE Siberia).

Distribution: Ryukyu Is. (3 Okinawa), Japan (Honshu, Shikoku, Kyushu, Tsu. shima), Korea, Manchuria, SE Siberia, Sachalin.

Fukuoka: Mt. Hiko. Oita : Mt. Kuju ; Mt. Sobo. Tokushima: Jinryo-mura in Myosai-gun ; Mt. Kenzan. Kochi: Nishigoya at Mt. Ishizuchi. Tokyo:Mt. Takao.

\section{Pyrrhalta fuscipennis (Jacoby)}

Galencella fuscipennis Jacoby, 1885, Zool. Soc. Lond., Proc. 1885: 746 (Japan: Awomori ; BM).

Clitena fuscipennis: Ogloblin, 1936, Fauna USSR 26, 1: 132, 392, fig. 56 (Amur, Japan).-Chûjô \& Kimoto, 1961, Pac. Ins. 3 (1): 160 (E. Siberia, Korea, Japan).

Pyrrhalta fuscipennis: Gressitt \& Kimoto, 1963, Pac. Ins. Mon. 1B: 450 (Japan, Korea, E. Siberia).

Distribution: Japan (Hokkaido, Honshu, Shikoku, Kyushu, Yakushima), Korea,

E. Siberia.

Kochi: Mt. Kuishi (1 ex., 18. Aug. 1950, K. Morimoto leg.).

Hosts: Acer spp. ; Populus spp. (after Chûjô \& Kimoto, 1961).

\section{Pyrrhalta tibialis (Baly)}

Galleruca tibialis Baly, 1874, Ent. Soc. Lond., Trans. 1874: 176 (Japan : Nagasaki ; $\mathrm{BM})$.

Clitena tibialis : Ogloblin, 1936, Fauna USSR 26, 1: 131, 392 (China, Japan).--Chûjồ \& Kimoto, 1961, Pac. Ins. 3 (1) : 161 (Japan, N. China).

Pyrrhalta tibialis: Gressitt \& Kimoto, 1963, Pac. Ins. Mon. 1B: 442, 466 (C. China).

Distribution: Japan (Honshu, Shikoku, Kyushu), C. China.

Fukuoka: Shira-shima in Wakamatsu City (1 ex., 23. Sept. 1954, T. Yoshida leg.) ; Sarakura-yama in Yahata City (1 ex., 30. July. 1953, T. Yoshida leg.). Kyoto: Daihi (1 ex., 27. May. 1950); Niomon (1 ex., 12, July. 1951, T. Horio leg.). 
Host: Celtis sinensis var. japonica (after Chûjô \& Kimoto, 1961).

\section{Pyrrhalta seminigra (Jacoby)}

Galerucella seminigra Jacoby, 1885, 2001. Soc. Lond., Proc. 1885 :744 (Japan :Yagohara ; BM).

Galentcella (Xanthogaleruca) seminigra: Ogloblin, 1936, Fauna USSR 26, 1: 111, 386 (Japan),

Cliten ı seminigra: Chûjô \& Kimoto, 1961, Pac, Ins. 3 (1) : 160 (Japan).

Pyrrhalta seminigra: Gressitt \& Kimoto, 1963, Pac. Ins. Mon. 1B: 411 (Japan).

Distribution: Japan (Hokkaido, Honshu, Shikoku, Kyushu).

Oito: Mt. Sobo (1 ex., 6. Aug. 1954, H. Kamiya leg.). Tokushima: Jinryo-mura in Myosai-gun (1 ex., 20. July. 1952, I. Hiura leg.). Aomori: Yunomata in Shimokita Pen. (1 ex., 20. July. 1956, K. Morimoto leg.). Hokkaido: Mt. Hakodate in Oshima Pen. (1 ex., 31. July. 1959, H. Kamiya leg.).

\section{Pyrrhalta isshikii (Chûjô) New Combination}

Galciaca (Isshikia) isshikii Chûjo, 1961, Ent. Lab., Univ. Osaka Pref., Pub. 6: 86 (Naze in Amami-Oshima ; CHuso).

Pyrrhalta nigricornis Ohno, 1962, Kontyû 30 (1) : 27 (Amami-Oshima ;Onno). New Synonymy

Distribution: Ryukyu Is. (Amami-Oshima).

Amamigroup: Amami-Oshima (4 ex., K. Matsui leg.).

Hosts: Viburnum suspensum, V. Awabuki (after Ohno, 1962).

\section{Genus Aulacophora Chevrolat}

Aulacophora Chevr., 1837, 'in Dejean, Cat. Col. ed. 2, 378, ed, 3, 402.--Duponchel\& Chevrolat, 1842, in d'Orbigny, Dict. Univ. d'Hist. Nat. 2: 337 (type :Galleruca quadraria Olivier ; Europe).--Chapuis, 1875, Gen. Col. 11: 158.-Weise, 1886, Ins, Deutschl. 6 (4) :574.--Laboissière, 1929, Soc. Ent. France, Ann. 98 (3): 256.Maulik, 1936, Fauna India, Galeruc., 169.-Hincks, 1949, Ann. Mag. Nat. Hist. ser. 12, 2 : 609; 1950, op. cit. 3 :87.-Chen\& Kung, 1959, Acta Ent. Sinica 9 (4) : 273.--Chûjô, 1962, Philip. Jour. Sci. 91 (1-2): 14, 74.-Gressitt \& Kimoto, 1963, Pac. Ins. Mon. 1B: 393, 482.

Raph idopalpa Chevr., 1845, in d'Orbigny,Dict. Univ. d'Hist. Nat. 6: 5 (type : Crioceris abdominalis Fab. ; Europe).-Hincks, 1949, Ann. Mag. Nat. Hist. ser. 12, 2 : 620; 1950, op. cit. 9: 88.

Rhaphidopalpa: Rosenhauer, 1856, Tiere Andalus., 325 (type :Galleruca foveicollis Lucas ; Europe).-Ogloblin, 1936, Fauna USSR 26, 1: 19, 150, 370, 396.--Hincks, 1949, Ann. Mag. Nat. Hist. ser. 12, 2 : 621.

Ceratia Chapuis, 1.876, Soc. Ent. Belg., CR. 19: c (type: Aulacophora marginalis Chapuis).--Laboissière, 1929, Soc. Ent. France, Ann. 98 (3): 257.

Triaplatys Fairmaire, 1877, Petites Nouvelles Ent. 2 (185) : 186 ; 1879, Mus. Godeffroy, Jour. 14: 118.

Orthaulaca Weise, 1892, Dtsch. Ent. Ztschr. 1892: 392 (type :Galeruca similis Oliv.; SE Asia).

Cerania Weise, 1892, Dtsch. Ent. Ztschr. 1892: 392 (type: Aulacophoracormuta Baly; SE Asia). -Laboissière, 1929, Soc. Ent. France, Ann. 98 (3): 256. 
Spaerarthra Weise, 1892,t. c. 392 (type : Aulacophora cyanoptera Boisduval ; New Guinea).-Laboissière, 1929, Soc. Ent. France, Ann. 98 (3): 257.

\section{Key to Japanese species of Aulacophora}

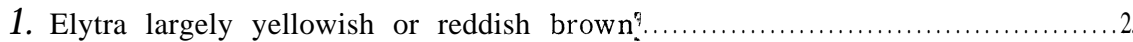

Elytra black or blue or green

2. In male elytra with a tuft of hairs on humeri, and first antennal joint robuster than in female, fifth (visible) abdominal segment trilobed and median lobe deeply excavated on middle and clearly longer than lateral one; in female fifth (visible) abdominal segment sharply notched at apex and its lateral portion clearly depressed ; reddish or yellowish brown; meso- and metathorax and middle and hind legs black, antennae reddish brown but in many cases preceding joints darkened ; rather smaller in size ; length $5.6-7.3 \mathrm{~mm} \ldots \ldots \ldots$.

femoralis

In male elytra without a tuft of hairs on humeri, first antenna1 joint normal, fifth (visible) abdominal segment trilobed and median lobe with almost flat surface and not longer than lateral one; in female fifth (visible) abdominal segment entire and rounded at apex; reddish brown, in some specimens each elytron with two or three pairs of black spots, of which one situated near scutellum, one at humeri and another behind middle, abdomen and both of middle and hind legs black, in some cases preceding joints of antennae darkened; rather large in size; length 7.6-8.3 $\mathrm{mm}$........... bicolor

3. Ventral surface of meso- and metathorax black; elytra black or blue or greenish blue ; head, prothorax and abdomen reddish brown, antennae and

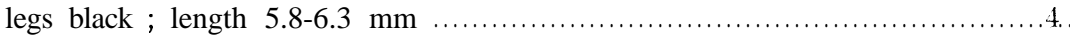

Ventral surface entirely reddish or yellowish brown $\ldots \ldots \ldots \ldots \ldots \ldots \ldots \ldots . \ldots . \ldots \ldots$

4. Elytra black .........................................nigripennis nigripennis

Elytra blue or greenish blue ..........................nigripennis nitidipennis

5. In male third antennal joint robuster than female, and second joint slightly robuster than female and its apical portion produced laterally, fifth (visible) abdominal segment trilobed, and its median lobe very deeply excavated on middle; in female third to fifth antennal joints subequal to each other in length ; elytra bluish green ; head, pronotum and abdomen yellowish brown; antennae and legs largely black ; length $7.5-9-0 \mathrm{~mm} \ldots \ldots \ldots \ldots \ldots$ loochooens is

In male thrid to sixth antennal joints slightly robuster than female, second joint normal ; in female third antennal joint slightly longer than fourth, the latter distinctly longer than fifth; head, pronotum, abdomen, antennae and legs yellowish brown; elytra black; length 5.3--6.0 $\mathrm{mm}$........... lewisii

\section{Aulacophora bicolor (Weber)}

Galleruca bicolor Weber, 1801, Qbs. Ent., 56 (Sumatra).

Galeruca sexpunctata Oliv., 1808, Ent. 6: 627, pl. 2, fig. 29 (Timor).

Aulacophora 6-punctata: Schönfeldt, 1890, Ent. Nachr. 16 (11): 174 (Loochoos : Oshima).

Aulacophora bicolor: Chûjô, 1935, Nat. Hist. Soc. Formosa, Trans. 24: 205 (Loochoos: Iriomote, Ishigaki).- Chû jô \& Kimoto, 1961, Pac. Ins. 3 (1): 158 (Sunda 
I., Ceylon, Philippines, Taiwan, Ryukyu Is.).-Chûjô, 1962, Phil. Jour. Sci. 91 (1-2) : 77, 86 (India, Andaman Is., Nicobar Is., Sumatra, Java, Timor, Philippines, Formosa, Loochoos).--Gressitt \& Kimoto, 1963, Pac. Ins. Mon. 1B: 483, 484 (China, Taiwan, Ryukyu Is., Philippines, SE Asia, Indonesia).

The specimens taken from Okinawa Is. and Amami-Oshima are all f. sexpunctata and those from Sakishima group are all the naminate form.

Distribution: SE Asia, Taiwan, Ryukyu Is. (Iriomote, Ishigaki, Okinawa, Amami-Oshima).

Sakishima group: Ishigaki Is., Iriomote Is. (after Nakane \& Kimoto, 1961). Okinawa group : Okinawa Is. (after Nakane \& Kimoto, 1961). Amami group: Amami-Oshima (after Nakane \& Kimoto, 1961); Kakeroma Is.

Hosts: Cucurbitaceae spp. (after Chûjô \& Kimoto, 1961).

\section{Aulacophora lewisii Baly}

Aulacophoralewisii Baly, 1886, Linn. Soc. Lond., Jour. 20: 5, 24 우 (China ;BM).-Chen, 1959, Acta Ent. Sin. 9 (4): 375, 378 (India, Hongkong).-Gressitt \& Kimoto, 1963, Pac. Ins. Mon. 1B: 484,488 (India, Ceylon, SE Asia, China, Loochoos, Japan).

Orthaulaca (Ceratia) cattigarensis Ws., 1892, Dtsch. Ent. Ztschr. 1892 : 397 (Japan ; Shanghai).

Aulacophora cattigarensis: Ogloblin, 1936, Fauna USSR 26, 1: 156, 397, fig. 65a (Japan, China, Annam, Tonkin, Cochin-China).-Chûjo, 1957, Kontyû 25 (1): 15 (Loochoos: Amami-Oshima).-Chen, 1959, Acta Ent. Sin. 9 (4): 375, 379, figs. 6-7 China, India, Vietnam, Japan).--Chûjô \& Kimoto, 1961, Pac. Ins. 3 (1): 158 (Japan, Ryukyu, S. China, Indo-China).-Chûjo, 1962, Phil. Jour. Sci. 91 (I-2j: 78, 99 (China, Indo-China, Japan, Loochoos, Formosa, incl. Percadore, Samosana).

Distribution: India, Ceylon, SE Asia, Japan (Yakushima), Ryukyu Is. (Iriomote, Ishigaki, Miyako, Okinawa, Amami-Oshima), Taiwan.

Okinawa group: Okinawa Is. (after Nakane \& Kimoto, 1961). Amami group: Amami-Oshima (after Nakane \& Kimoto, 1961).

Hosts: Cucurbitaceae spp. (after Chûjô \& Kimoto, 1961).

\section{Aulacophora femoralis (Motschulsky)}

Rhaphidoplapa femoralis Mots., 1857, Etud. Ent., 6 : 37 (Japan).-Ogloblin, 1936, Fauna USSR 26, 1: 154, 396 (Korea, ? China, Japan).

Aulacophora femoralis: Chen \& Kung, 1959, Acta Ent. Sin. 9 (4): 375, 385 (Taiwan, Japan, ? Korea).-Chû jô \& Kimoto, 1961, Pac. Ins. 3 (1): 158 (Japan, Ryukyu Is., Korea, N. China).-Gressitt \& Kimoto, 1963, Pac. Ins. Mon. 1B: 483, 486 (E. Siberia, China, Hainan, Vietnam, Korea, Japan).

Distribution: Japan (Honshu, Aogashima, Hachijo-jima, Hachijo-kojima, Awashima, Sado I., Oki I., Shikoku, Okinoshima, Kyushu, Tsushima, Yakushima, Kuchioerabu-jima), Ryukyu Is. (Tokara, Amami-Oshima, Kita \& Minami-Daito-jima, Okinawa, Taketomi, Miyako, Ishigaki, Iriomote), Korea, China, Taiwan.

Sakishima group: Miyako Is. Iriomote Is. \& Ishigaki Is. (after Nakane \& Kimoto, 1961). Okinawa group: Okinawa Is. (after Nakane \& Kimoto, 1961). Amami group: Amami-Oshima (after Nakane \& Kimoto, 1951). Tokara group: Nakanoshima \& Takarajima (after Nakane \& Kimoto, 1961).

Fukuoka: Fukuoka City. Kumamoto:Tatsuta-yama in Kumamoto City. Yaku- 
shima: Amboo. Kochi: Kuroson. Okayama: Kamo-cho in Tomata-gun. Kyoto: Yoshida in Kyoto City. Fukui: Mt. Murakuni in Takefu City. Yamanashi:Shosenkyo; Komagatake. Miyagi: Sendai City.

Hosts: Cucurbitaceae spp. (after Chûjô \& Kimoto, 1961).

\section{A ulacophora loochooensis Chûjồ}

Aulacophora loochooensis Chûjô, 1957, Kagawa Univ., Mem. Fac. Lib. Arts \& Educ. 2 (52): 2 (Loochoos : Shinmura-Akatsuchiyama in Amami-Oshima ; ChL.so).Chûjô \& Kimoto, 1961, Pac. Ins. 3 (1): 158 (Ryukyu Is.).

Distribution : Ryukyu Is. (Amami-Oshima).

A mami group: Yuwan in Amami-Oshima (2 exs., 5. Apr. 1958, M. Takahashi leg.); Shinmura in Amami-Oshima (1 ex., 2. Apr. 1958, M. Takahashi leg.).

Hosts: Cucurbitaceae spp. (after Chûjô \& Kimoto, 1961).

\section{Aulacophora nigripennis nigripennis Motschulsky}

A ulacophora nigripennis Mots., 1857, Etud. Ent. 6: 38 (Japan).--Ogloblin, 1936, Fauna USSR 26, 1: 156, 397, figs. 64, 65b (Amur, China, Japan).-Chû́ jô \& Kimoto, 1961, Pac. Ins. 3 (1): 159 (Japan, Korea, E. Siberia, Manchuria, China, Formosa). —Chûjô, 1962, Phil. Jour. Sci. 91 (1-2): 79, 91 (Japan, Loochoos, Formosa, Korea, Manchuria, China, Amur, Ussuri).--Gressitt \& Kimoto, 1963, Pac. Ins. Mon. 1B: 484, 489 (E. Siberia, China, Korea, Japan).

Distribution : E. Siberia, Manchuria, China, Taiwan, Korea, Japan (Honshu, Awa-shima, Sado I., Oki Is., Shikoku, Okinoshima, Kyushu, Tsushima, Goto Is., Yakushima)

Fukuoka: Magaribuchi in Sawara-gun; Tashiro in Yame-gun; Mt. Wakasugi; Mt. Hiko ; Nishi-koen, Hirao in Fukuoka City; Kokura City ; Mt. Kora in Kurume City ; Shikanoshima in Kasuya-gun ; Mt. Fukuchi; Shirashima in Wakamatsu City. Kagoshima : Sata-misaki. Miyazaki: Mt. Osuzu. Yakushima : Amboo. Kochi: Ashizuri-misaki. Kyoto: Kibune in Kyoto City. Nara: Mt. Yoshino. Kanagawa: Yugawara. Miyagi: Sendai City.

Hosts : Cucurbitaceae spp. (after Chûjô \& Kimoto, 1961).

\section{A ulacophora nigripennis nitidipennis Chû jô}

Aulacophora (Ceratia) nitidipennis Chûjô, 1935, Nat. Hist. Soc. Formosa, Trans. 25: 82 (Loochoos: Nago in Okinawa; Naze in Amami-Oshima; Iriomote I.).

Aulacophora nigripennis nitidipennis : Chûjô \& Kimoto, 1961, Pac. Ins. 3 (1): 159 (Ryukyu Is.).

Distribution: Ryukyu Is. (Amami-Oshima, Okinawa, Ishigaki, Iriomote).

Sakishima group: Ishigaki Is. (after Nakane \& Kimoto, 1961). Okinawa group:

Okinawa Is. (after Nakane \& Kimoto, 1961). Amami group: Amami-Oshima (after Nakane \& Kimoto, 1961).

Hosts : Cucurbitaceae spp. (after Chûjô \& Kimoto, 1961).

\section{Genus Oides Weber}

Oides Weber, 1801, Obs. Ent., 26 (type : Chrysomela bipunctata F.).-- Laboissiere, 1922, Soc. Ent. France, Ann. 90: 194.--Maulik, 1935, Fauna India, Galeruc., 105. 
-Ogloblin, 1936, Fauna USSR 26, 1: 18,145, 395.--Hincks, 1949, Ann. Mag. Nat. Hist. ser. 12, 2 :617.-Chû jo, 1962, Phil. Jour. Sci. 91 (1-2): 14, 61.-Gressitt \& Kimoto, 1963, Pac. Ins. Mon. 1B: 392, 474.

Adorium Fabricius, 1801, Syst. Ent. 1: 409 (type : Chrysomela bipunctata F.).Chapuis, 1875, Gen. Col. 11: 156.

Ochralea Chevrolat, 1837, in Dejean, Cat. Col. ed. 2, 375, ed. 3, 399 (type: Adorium favum Olivier, 1807 ; monobasic) ; 1845, in d'Orbigny, Dict. Univ. d'Hist. Nat. 6: 5; 1846, loc. cit. 8: 713.-Hincks, 1949, Ann. Mag. Nat. Hist. ser. 12, 2 : 617.

Rhombopalpa Chevrolat, 1837, in Dejean, Cat. Col. ed. 2, 375, ed. 3, 399 (type : Adorium decempunctata Billberg ; monobasic) ; 1845, in d'Orbigny, Dict. Univ. d'Hist. Nat. 6: 5.-Hincks, 1949, Ann. Mag. Nat. Hist. ser. 42, $2: 617$.

Botanctona Fairmaire, 1877, Petites Nouvelles Ent. 2 (185) : 185; 1897, Mus. Godeffroy, Jour. $14: 113$.

Boisduvallia Montrouzier, 1885, Soc. Agr. Lyon, Ann. $7: 72$.

\section{0 ides bow ringii (Baly)}

Adorium bowringii Baly, 1863, Ent. Soc. Lond., Trans. ser. 3, 1: 623 (China : Hong Kong ; BM).

Oides bowringi : Seki, 1933, Konchu-kai 1 (5): 494 (Japan :Kobe).-Ogloblin, 1936, Fauna USSR 26, 1: 149,396 (Korea, China, Japan).-Chûjô \& Kimoto, 1961, Pac. Ins. 3 (1): 167 (China, Korea, Japan).-Gressitt \& Kimoto, 1963, Pac. Ins. Mon. 1B: 475, 476 (S. China, Korea, Japan).

Large in size, round, strongly convex; yellowish brown; elytra largely bluish black with lateral and apical margins broadly and sutural margin narrowly yellowish brown; antennae yellowish brown with four apical joints blackish; legs yellowing brown with tarsi and apex of tibiae blackish; length 13-15 mm.

Distribution: S. China, Korea, Japan (Honshu).

Hyogo: Karasubara in Kobe City (1 ex., 4. May. 1937, M. Uno leg.); Mt. Rokko in Kobe City (1 ex., 12. Aug. 1951, Y. Wada leg.).

Hosts : Kadsura japonica ; Schisandra nigra (after Chûjô \& Kimoto, 1961).

\section{Genus Clerotilia Jacoby}

Clerotilia Jac., 1885, 2001. Soc. Lond., Proc. 1885 : 751 (type : C. flavomarginata Jac.; Japan).--Ogloblin, 1936, Fauna USSR 26, 1: 217, 370.-Gressitt \& Kimoto, 1963, Pac. Ins. Mon. 1B: 393, 479.

\section{Clerotilia flavomarginata Jacoby}

Clerotilia flavomarginata Jacoby, 1885, 2001. Soc. Lond., Proc. 1885: 751, pl. 46, fig. 12 (Japan : Tsumago, Nara; BM).--Ogloblin, 1936, Fauna USSR 26, 1: 218, 407 (Japan).--Chûjô \& Kimoto, 1961, Pac. Ins. 3 (1): 160 (Japan).-Gressitt \& Kimoto, 1963, Pac. Ins. Mon. 1B: 480, 482 (Japan, E. China).

Oblong, subparallel-sided, slightly convex ; antennae long, slender but in male third to eighth joints robuster than in female and strongly incrassiate at apex; pronotum smooth; elytra finely granulate, rather distinctly and closely punctate; reddish brown to dark reddish brown; elytra green with slight cupreous luster, and its lateral and apical margins narrowly brownish ; antennate piceous to black; length $4.3-5.8 \mathrm{~mm}$. 
Distribution : E. China, Japan (Honshu, Shikoku, Kyushu).

Fukuoka: Mt. Hiko; Mt. Fukuchi; Mt. Wakasugi; Hirao in Fukuoka City. Kochi: Jinzenji in Kochi City. Nagano: Karuizawa ;Ontake in Kiso-Fukushima. Yamanashi: Obinayama, Atago-yama in Kofu City.

Host : Rhamnella fragululoides (after Chû jô \& Kimoto, 1961).

\section{Genus Japonitata Strand}

Japonia Weise, 1922 (nec Gould), Tijdschr. Ent. 65: 70 (type :Phyllobroticanigrita Jacoby ; Japan)-Ogloblin, 1936, Fauna USSR 26, 1: 196, 371.

Japonitata Strand, 1935, Folia Zool. Hydrobiol. 7: 294 (new name for Japonia

Weise, nec Gould, 1859).--Gressitt \& Kimoto, 1963, Pac. Ins. Mon. 1B:394,501.

\section{Japonitata nigrita (Jacoby)}

Phyllobrotica nigrita Jacoby, 1885, 2001. Soc.Lond., Proc. 1885 :742, pl. 46, fig. 3 (Japan : Osaka ; BM).

Japon in nigrita: Ogloblin, 1936, Fauna USSR 26, 1: 196, 403 (Japan).

Japonita ta nigrita: Chû jô \& Kimoto, 1963, Pac. Ins. 3 (1): 165 (Japan).---Gressitt \& Kimoto, 1963, Pac. Ins. Mon. 1B: 501 (Japan).

Oblong ovate, convex; pronotum smooth, 'impunctate and with a pair of depres. sions laterally; elytra with two pairs of lateral costae, which start from humerus and of which interior one is interrupted at base; shining black, abdomen yellowish ; length $4.0-5.8 \mathrm{~mm}$.

Distribution: Japan (Honshu, Shikoku, Kyushu).

Fukuoka: Mt. Hiko (1 ex., 15. Aug. 1954, T. Okuma leg.). Kumamoto: Mt. Ichifusa (1 ex., 26. July. 1952, S. Kimoto leg.). Kochi: Ashizuri-misaki (1 ex., 27. Apr. 1956, Y. Wake leg.). Kyoto: Seriu (1 ex., 14. June. 1954, M. Nakayama leg.). 